\title{
The significance of local meteorological stations in research planning
}

\author{
Zsuzsanna Novák - Lajos Juhász - Sámuel Zsolt Varga \\ University of Debrecen, Faculty of Agricultural and Food Sciences and Environmental Management \\ Institute of Animal Science, Biotechnology and Nature Conservation, Debrecen \\ novakzsu@agr.unideb.hu
}

\section{SUMMARY}

\begin{abstract}
The goal of research planning is to optimize human and material resources while maximizing efficiency. If there are databases that can be used as a substitute for own data collection, effective research can be facilitated by reallocating resources. In the case of environmental studies, the knowledge of the climatic conditions of the study period is known to be a key factor in research planning process.

In the present study, the data of our meteorological station in our research area (known as "Szamárháti Tanya", Kesznyéten, Hungary) was compared with the measurements of meteorological stations operated by the competent water authority. Stations were taken into the study within a 10 and $20 \mathrm{~km}$ radius over a period of 21 months, to determine which provided more relevant data from the area.

During the evaluation of results, the relationship between the local and regional weather stations were determined, and deductions were made from the obtained results to support the decision which of the targeted investigations could be of greater benefit.
\end{abstract}

Keywords: agro-meteorology, research design, temperature, precipitation, measuring station

\section{INTRODUCTION}

The fundamental pillar of research planning is the in-depth examination of background data. Climatic measurements are needed to facilitate proper the selection of research methods according to baseline surveys.

To achieve the proper level of knowledge, existing meteorological datasets or targeted measurement programs can be used. (Loksa, 2004)

Meteorological data can be widely used to support research methods, e.g. added local meteorological data can improve the interferometric radar measurement accuracy performed on rock-slide areas (Norland, 2007). However, meteorological datasets are simple, they provide support to discover complex events, and subserve forecasts of ecological disasters and anomalies (Neves et al., 2007).

There are plenty of options when it comes to using existing data, but in any case, it has to be considered how realistic the data is. Usability is affected by the circumstances of data acquisition, the placement of the meter, and calibration. If these are taken into consideration, the amount of usable data is greatly reduced. In order to be able to properly compare the data in each case, the circumstances of their generation must be clarified (Szász and Tőkei, 1997).

Most of these types of data are collected, systematized, and processed by the National Meteorological Service and can be requested from the Climate Information Unit of the OMSZ (Tökei, 1988; Varga-Haszonits et al., 2000).

We can also use regular measurements that are not provided by the OMSZ for data collection. Many organizations and institutions regularly carry out such surveys in their area of competence. These include: Plant Protection and Veterinary Stations, Small and Large-scale Agricultural, Forestry, Road Directorates, The Hungarian Railways, Sports Airports, Water Directorates. These organizations carry out accurate meteorological and climatological surveys in connection with their activity profile, so these data are often specialized and cannot be used in other fields. However, their general data (temperature, precipitation) is always accurate and controlled. It is common that we do not have adequate microclimatic data for the selected plot. In this case, local instrumental measurement is the solution. The most accurate results can be obtained by long-term operation and data processing of the measuring instrument installed in the test area. (Loksa, 2004).

Locally owned, resource-driven meteorological stations can provide benefits in special cases. For the use of the main meteorological data for research purposes, the services of the territorially competent water authorities are available free of charge in accordance with the law act No. CXII. on selfdetermination and freedom of information. However, their relevance should be verified at the early planning stage of each study.

The purpose of this study is to determine whether regional data collected by water authorities is sufficient in a given geographical region or own datasets are needed to minimize distortions. We also wanted to express, if geographical distance has an effect on the collected data.

\section{MATERIALS AND METHODS}

\section{Data collection}

Our data collection was performed at Szamárhát Visitor Center in the Kesznyéten Landscape Protection Area. The Center is maintained by the Tiszatáj Public Foundation, which has its own meteorological station in the area. This database had been compared with data from the relevant water authorities' measuring stations.

Measurements were taken with a Technoline WS2800IT type meteorological device that includes a wind sensor, a precipitation sensor, a thermo-hygro sensor and a wireless receiver. The distant sites for comparison 
were selected 10 and $20 \mathrm{~km}$ afar from our station. Because there are no stations at exactly this distance, the closest measuring points were considered. For this reason, a dataset representing a distance of $10 \mathrm{~km}$ was obtained from the Tiszadob station, which was maintained by the Northern Hungarian Water Directorate, and the requested data from the Tiszántúl
Water Directorate was provided by Folyás meteorological station. During the selection of the of the reference points, attention was paid to the fact that there are no macro terrain factors between the 3 points that can significantly alter the climatic conditions even in small areas (Figure 1).

Figure 1: The location of meteorological station in the research area

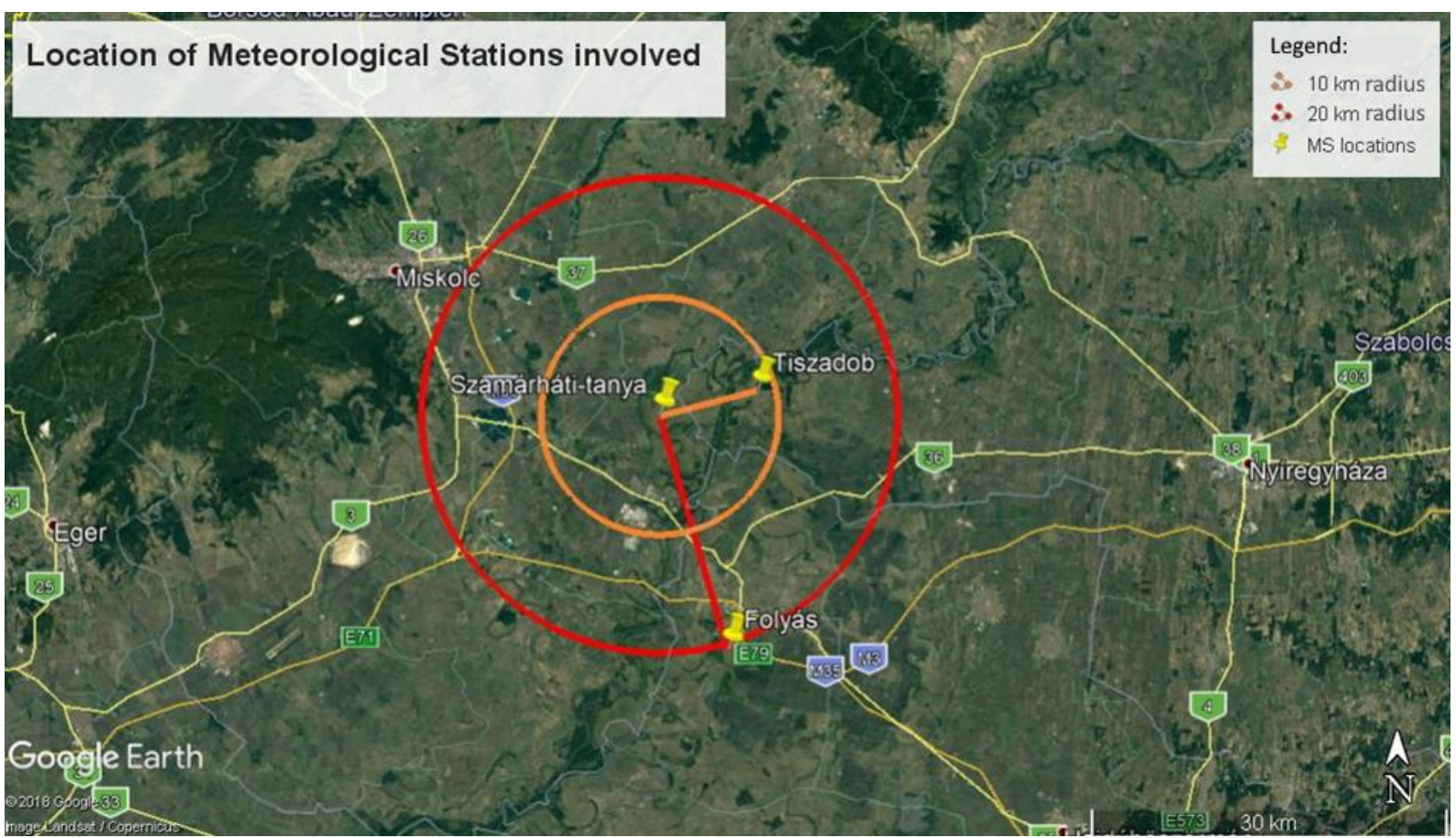

\section{Data processing}

The data sets from different locations were obtained in data tables of different structure, so the first step was to sort and unify the data. We processed a raw dataset of more than 30.000 data from January 1, 2018 to October 30, 2019, from which monthly mean temperatures and monthly precipitation amounts were calculated.

\section{Statistical evaluation}

The sorted data were evaluated by statistical tests using SPSS 25.0 software. First, a normality test was performed and then the Kruskal-Wallis test was used to examine the relationships between the stations.

\section{RESULTS}

\section{Temperature}

During the research period temperature values were nearly homogenous among the three observation points (Figure 2). However, there were deficiencies in the Kesznyéten data set resulted by a software failure in which the unit has recorded the data but was not accessible to the central unit, differences were not significant. In Table 1 we can see that there is no significant difference between our collected data and the values provided by nearby stations.

Temperature values were compared by KruskalWallis test which has confirmed that no significant Folios difference (Kruskal-Wallis test: $1.859, \mathrm{p}=0.839$, $\mathrm{n}=48$ measurements in 3 stations).

Table 1

Descriptive statistics of temperature values in the three stations

\begin{tabular}{lcccc}
\hline \multicolumn{2}{c}{ Temperature } & Kesznyéten & Tiszadob & Folyás \\
\hline N & Valid & 10 & 21 & 21 \\
& Missing & 11 & 0 & 0 \\
Mean & 10.85 & 12.23 & 12.85 \\
Median & 9.75 & 14.30 & 14.70 \\
Std. Deviation & 10.04 & 8.60 & 8.94 \\
Range & 24.40 & 25.00 & 25.40 \\
Minimum & -0.50 & -1.90 & -1.30 \\
Maximum & 23.90 & 23.10 & 24.10 \\
\hline
\end{tabular}




\section{Figure 2.: Temperature data of the three stations}

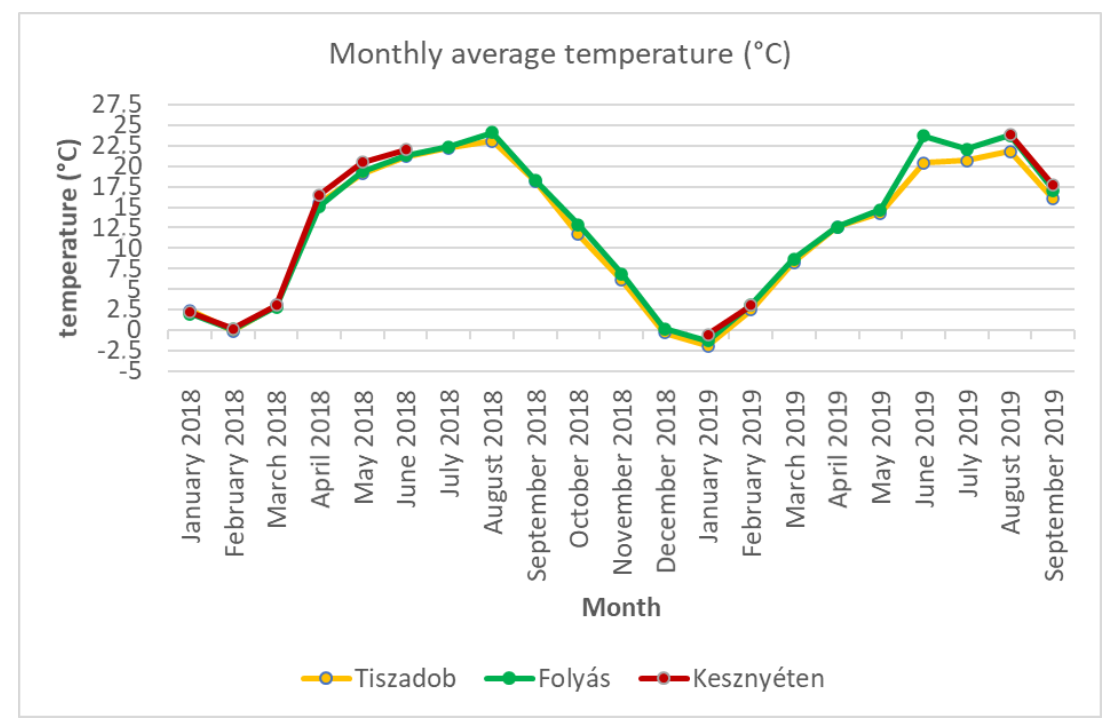

\section{Precipitation}

Similarly to temperature datasets there were also a lack of data in our own measurements for the formerly introduced issue in the software of the recording unit. In this case the precipitation values seemed to be significantly different among the stations (Table 2), but the Kruskal-Wallis test revealed that these differences are not significant (Kruskal-Wallis test: 1.859, $\mathrm{p}=0.395, \mathrm{n}=48$ measures from 3 stations).

\begin{tabular}{|c|c|c|c|}
\hline Humidity & Kesznyéten & Tiszadob & Folyás \\
\hline Valid & 6 & 21 & 21 \\
\hline Missing & 15 & 0 & 0 \\
\hline Iean & 27.42 & 43.08 & 41.60 \\
\hline Median & 22.35 & 32.20 & 36.00 \\
\hline td. Deviation & 27.40 & 38.97 & 23.37 \\
\hline ange & 72.10 & 165.90 & 91.60 \\
\hline linimum & 3.90 & 1.80 & 2.20 \\
\hline Iaximum & 76.00 & 167.70 & 93.80 \\
\hline
\end{tabular}

Figure 3: Humidity data of the three stations

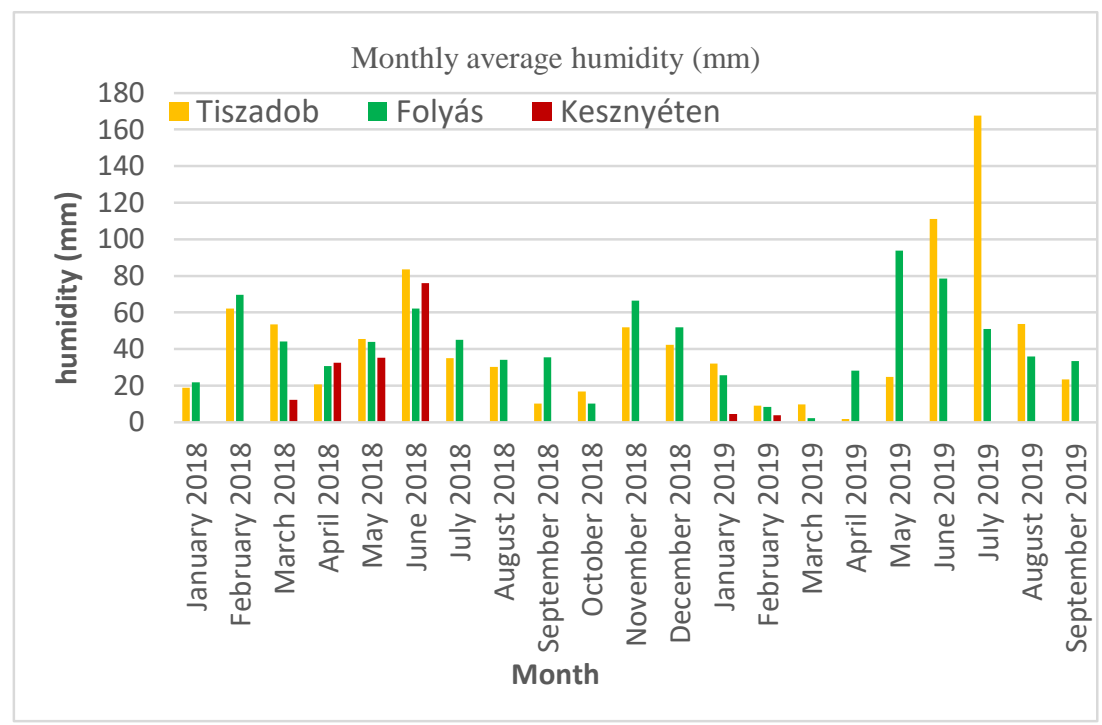




\section{SUMMARY}

In total, we can state that local meteorological stations within a range of 20 kilometres have the same efficiency in measuring temperature. However, in average, there was no difference between precipitation values distribution among the stations (Figure 4), the monthly differences can be important if we are planning a research with species' that are vulnerable to under-, or over-irrigation (Figure 3). The precision of these datasets is depending on the area of the observation, and the geographical distance from the data recording unit.

If the observation area is not mainly characterised by temperature and precipitation conditions, further stations can be used for gathering weather data.

Figure 4: Summary of statistical evaluation

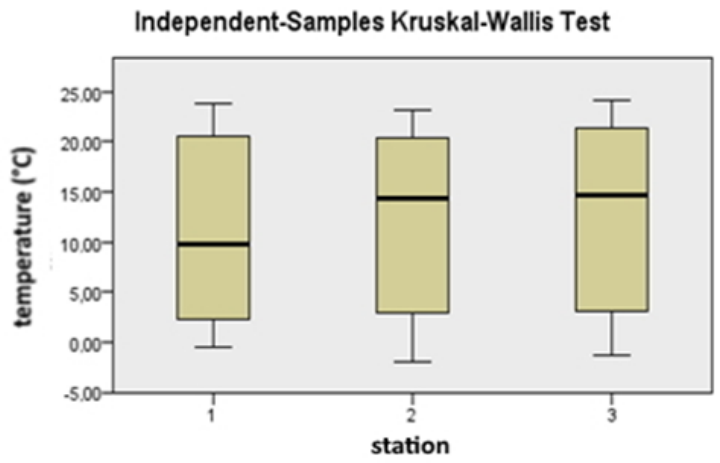

\section{DISCUSSION}

Based on the process of data requests and the experience of systematisation and evaluation work, it can be stated that local stations have the advantage of having access to the recorded data at any time, depending on the type, recording multiple data (e.g. humidity, wind speed, air pressure). Because these devices are small in size, you can place them where you want to take measurements. Therefore, they are suitable for measurements of microclimatic factors and the effects of micro terrain. The disadvantage is that it requires constant maintenance and verification, even if the data is not always downloaded from the device. In addition, the installation of a local station will always entail financial costs and will require IT and meteorological expertise from the installer.

In contrast to this, free access to water authority data is reliable and instrument maintenance is regularly performed by professionals. The disadvantage is that the process of requesting data is lengthy and the data received is not uniform, it is time-consuming to systematize and make it transparent. If you want to use this data, you must always choose the location of your data carefully, as the measuring instruments of each climatic element may not always be in one place and

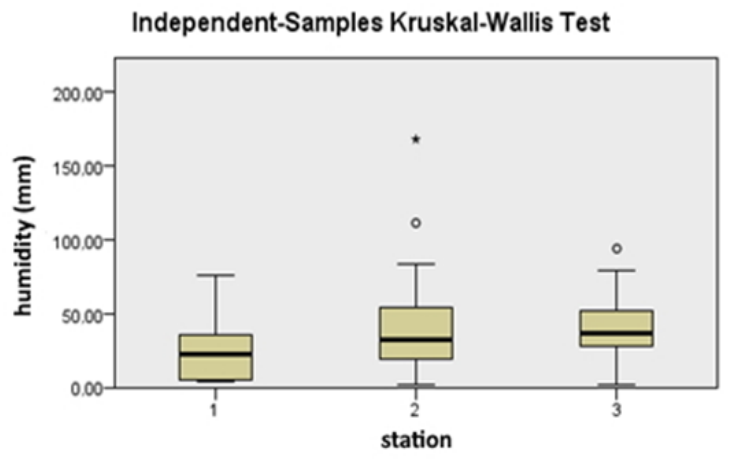

the terrain elements can greatly influence the usability of the data.

All in all, there is no significant difference between the data provided by the local measuring station and the water authority. Furthermore, contrary to expectations, the relevance of the data in the Great Plain area is not affected by the presence of the measuring station in the investigated area or within 10 and $20 \mathrm{~km}$ of it, which provides climatic data.

Basically, research planning requires preliminary data collection on what alternative sources of data are available to us. If the success of the research can be influenced by the microclimatic factors and the microrelief, or our research is specifically aimed at investigating these, then it is recommended to include the local measuring station (s) in the data collection. If the knowledge of the basic climatic factors is sufficient for us, then the information of the water directorates is sufficient.

\section{ACKNOWLEDGEMENTS}

The publication is supported by the EFOP-3.6.3VEKOP-16-2017-00008 project. The project is cofinanced by the European Union and the European Social Fund. 


\section{REFERENCES}

Loksa, G. (2004): Meteorológia a tájökológia szolgálatában, Tájökológiai Lapok 2 (2): 195-199.

Neves, J.M.-Santos, M.F.-Machado, J.M. (2007): A data mining approach to predict forest fires using meteorological data, New trends in artificial intelligence: proceedings of the 13th Portuguese Conference on Artificial Intelligence (EPIA 2007), Guimarães, Portugal, APPIA,. p. 512-523.

Norland, R. (2007): Improving interferometric radar measurement accuracy using local meteorological data. In: Proceedings of the IEEE international geoscience and remote sensing symposium 2007, Barcelona

Szász, G.-Tőkei, L. (1997): Meteorológia. Mezőgazda Kiadó, Budapest.
Tőkei, L. (1988): Táj- és kertépítészeti meteorológia. Egyetemi jegyzet, KÉE Budapest.

Unger, J. 1977: Lokális és mikroklímák. Egyetemi jegyzet, JATE Szeged

Varga-Haszonits, Z.-Varga, Z.-Lantos, Zs.-Vámos, O.-Schmidt, R. (2000): Magyarország éghajlati erőforrásainak agroklimatológiai elemzése. Mosonmagyaróvár.

2011. évi CXII. törvény “az információs önrendelkezési jogról és az információszabadságról" 
